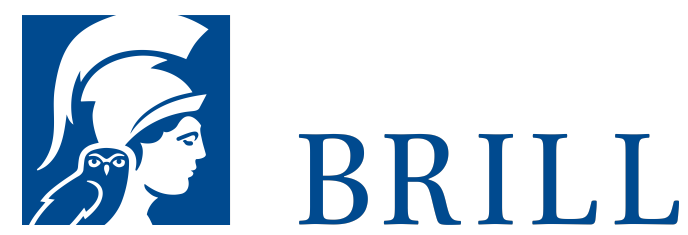

\title{
Idioten des Absoluten
}

Über das Weltfremde in uns

\section{Author: Peter Strasser}

Peter Strassers neues Buch hat eine zentrale These, um welche die teilweise persönlich gehaltenen Reflexionen kreisen: Erst das Weltfremde in uns ermöglicht uns Beheimatung in der Welt. Wer nicht schon einmal selbst so dachte, wird auf die große Idioten-Literatur des Abendlandes verwiesen. Der moderne Idiot ist ein Weltfremder. Aber eben darin wurzelt seine Gabe, die Welt als einen Ort zu erfahren, wo es gerade die sich nahenden, sich der Anschauung öffnenden Phänomene sind, in denen eine letztmögliche Nähe zur Welt aufscheint.

Dieses Aufscheinen transzendiert das Faktische, wie es uns die Wissenschaft vermittelt; zugleich wird im sinnlich Intimen, im Bedingten und Flüchtigen, die Realpräsenz eines Absoluten, »Göttlichen «, spürbar. So streben, rational uneinholbar, die Dinge auf einen Horizont zu, den man früher »Schöpfung « nannte: den Beheimatungshorizont im Welt-Exil.

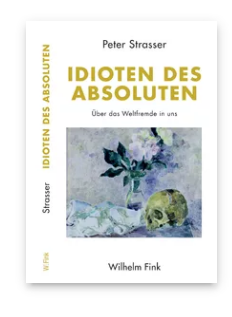

Pages: 133

Seiten

Language:

German

Subjects:

General, Philosophy

Publisher: Brill |

Fink

E-Book (PDF)

Released online: 04 Sep 2017

ISBN: $978-3^{-}$ 8467-6259-2

List price

Paperback

Publication date:

14 Jul 2017

ISBN: 978-3-

7705-6259-6

List price 
For more information see brill.com

Order information: Order online at brill.com +44330 333 0049 | customerservices@brill.com Submission information: brill.com/authors

Titles published by Brill | Fink, Brill | mentis or Brill | Schöningh: +49(o)715413279216| brill@brocom.de 